\title{
Relationship of root biomass and soil respiration in a stand of deciduous broadleaved trees - a case study in a maple tree
}

\author{
Jae-Seok Lee(i)
}

\begin{abstract}
Background: In ecosystem carbon cycle studies, distinguishing between $\mathrm{CO}_{2}$ emitted by roots and by microbes remains very difficult because it is mixed before being released into the atmosphere. Currently, no method for quantifying root and microbial respiration is effective. Therefore, this study investigated the relationship between soil respiration and underground root biomass at varying distances from the tree and tested possibilities for measuring root and microbial respiration.
\end{abstract}

Methods: Soil respiration was measured by the closed chamber method, in which acrylic collars were placed at regular intervals from the tree base. Measurements were made irregularly during one season, including high temperatures in summer and low temperatures in autumn; the soil's temperature and moisture content were also collected. After measurements, roots of each plot were collected, and their dry matter biomass measured to analyze relationships between root biomass and soil respiration.

Results: Apart from root biomass, which affects soil's temperature and moisture, no other factors affecting soil respiration showed significant differences between measuring points. At each point, soil respiration showed clear seasonal variations and high exponential correlation with increasing soil temperatures. The root biomass decreased exponentially with increasing distance from the tree. The rate of soil respiration was also highly correlated exponentially with root biomass. Based on these results, the average rate of root respiration in the soil was estimated to be $34.4 \%$ (26.6 43.1\%).

Conclusions: In this study, attempts were made to differentiate the root respiration rate by analyzing the distribution of root biomass and resulting changes in soil respiration. As distance from the tree increased, root biomass and soil respiration values were shown to strongly decrease exponentially. Root biomass increased logarithmically with increases in soil respiration. In addition, soil respiration and underground root biomass were logarithmically related; the calculated root-breathing rate was around $44 \%$. This study method is applicable for determining root and microbial respiration in forest ecosystem carbon cycle research. However, more data should be collected on the distribution of root biomass and the correlated soil respiration.

Keywords: Soil respiration, Root biomass, Carbon cycle, Carbon dioxide, Forest ecosystem

(c) The Author(s). 2018 Open Access This article is distributed under the terms of the Creative Commons Attribution 4.0 International License (http://creativecommons.org/licenses/by/4.0/), which permits unrestricted use, distribution, and reproduction in any medium, provided you give appropriate credit to the original author(s) and the source, provide a link to the Creative Commons license, and indicate if changes were made. The Creative Commons Public Domain Dedication waiver (http://creativecommons.org/publicdomain/zero/1.0/) applies to the data made available in this article, unless otherwise stated. 


\section{Background}

Understanding the forest carbon cycle is basal to elucidating the global carbon cycle scientifically. In forests, carbon absorbed into the ecosystem from the atmosphere is processed in several nutritional steps, and a large amount of carbon is returned to the atmosphere in the process. Quantitative analysis and understanding of the circulation and storage are also fundamental to understanding the material cycle of ecosystems (IPCC 2007; Lee et al. 2017).

In estimating the net amount of carbon fixed in plants, quantifying carbon released from the underground parts is unproblematic because carbon from emission sources other than the plant can easily be distinguished. However, carbon is also released from the ground by microbial respiration processes in the soil. It is technically difficult to separate these two components of respiration (Hanson et al. 2000), but to do so is of the utmost importance as the two fluxes vary dynamically. The two components of soil respiration are controlled by the supply of different $\mathrm{C}$ sources, dead organic matter (OM) and plant photosynthates, which may respond differently to variations in soil temperature (Boone et al. 1998).

This estimation is necessary for understanding the amount of carbon transported by producers and consumers at the ecosystem level to gain insight into the flow and storage at each nutritional level. In addition, estimating the input of atmospheric carbon into the ecosystem and its properties, including the flow through the ecosystem and the amount returned to the atmosphere, is the most basic data required for understanding the characteristics of the ecosystem's material cycle and energy flow.

Kucera and Kirkham (1971) reported that soil respiration increases with increasing root biomass and that root respiration accounts for $40 \%$ of total soil respiration; Chapman (1979) gave a value of $70 \%$ and Wang et al. (2009) reported about 40\%, while Coleman (1973) reported only 3 9\%. In Korea, Son and Kim (1996) reported about 3\% in a forest consisting of pitch pine (Pinus rigida Mill.) and Japanese larch (Larix kaempferi), and Lee et al. (2012) reported about 33.3 67\% in Quercus acutissima Carruth. forest. This large variation in the estimates of root respiration is a very big problem in understanding the carbon cycle of ecosystems.

The major research methods for measuring the respiration rate of the different sources in the soil are the following: (1) After dividing the roots into classes of varying thickness, directly measure the volume of roots in each category that are inserted per unit area in the soil layer (Vose and Ryan 2002). (2) A method has been proposed in which a certain area of a plot is isolated by digging a trench to the depth to which the roots extend and installing a root penetration prevention plate so that new roots cannot pass. This is a method to measure the respiration volume of an undisturbed area over a short period (trenching method, Hanson et al. 2000; Ryan and Law 2005; Lee et al. 2017; Lamberty et al. 2004; Kuzyakov and Larionova 2005). (3) The isotopic method (Millard et al. 2008), in which the ratio of $\mathrm{CO}_{2}$ isotopes generated from soil is analyzed, allowing the amount of respiration for each source to be calculated. However, despite these efforts to quantify the amounts of each biological element in the soil, no method has solved the issue. In conclusion, determination of the root respiration in soil is still dependent on rough estimates.

The purpose of this study was to investigate the relationship between the biomass of roots and the level of soil respiration at the base of trees in addition to comparing the various methods applied in the past and the possibility of applying them here. The distribution characteristics of the root biomass and the root respiration values at various distances from the base of the tree were therefore collected and analyzed.

\section{Methods}

This study was carried out on young seedlings of maple (Acer palmatum) in Korea's central area (N 37 $25^{\prime} 82^{\prime \prime}$, E $\left.122^{\circ} 05^{\prime} 36^{\prime \prime}\right)$, which had remained undisturbed for about 40 years. The trees grow in an area with reddish-brown forest soil and are spaced at more or less regular intervals. There is almost no gravel in the soil, and the development and distribution of the roots was relatively homogeneous.

Soil homogenization was performed between the measurement points to regularize the soil microbial respiration rate according to the distance to the trees. First, we removed organic matter and soil from the surface to a depth of $5 \mathrm{~cm}$, replacing this layer containing high organic matter with homogeneous soil taken from the surrounding soil at a depth of about $30 \mathrm{~cm}$.

Soil respiration was measured by the closed chamber method (Suh et al. 2006). Seven acrylic collars (diameter $16 \mathrm{~cm}$ ) were installed at regular intervals of $50 \mathrm{~cm}$ at distances of 120 to $420 \mathrm{~cm}$ from the tree base. Collars were fixed by inserting them up to a depth of $5 \mathrm{~cm}$. During the measurement period, litter that could affect the respiration rate, such as leaves and twigs, was removed from the collar at any time to keep the soil organic matter homogeneous. The measurement point at $420 \mathrm{~cm}$, where no roots are present, was set as the control to assess pure heterotrophic respiration. Also, it was used to calculate the ratio of root respiration to soil respiration.

Soil respiration was measured using a closed chamber cap of about $15 \mathrm{~cm}$ height that was installed with a $\mathrm{CO}_{2}$ sensor (GMP343, Vaisala, Finland) at the top inside. When the chamber cap was installed onto the collar top, the $\mathrm{CO}_{2}$ concentration in the closed space between the 
ground and the chamber cap increased with time. The rising rate of the $\mathrm{CO}_{2}$ was calculated taking several parameters, such as air temperature, atmospheric air pressure, and closed chamber volume, into account.

The soil respiration $\left(R_{\mathrm{s}}\right)$ was collected at irregular times for a month from summer to autumn and was calculated using the following equation:

$$
R_{s}\left(\mathrm{mg} \mathrm{CO}_{2} \mathrm{~m}^{-2} \mathrm{~h}^{-1}\right)=a \cdot \rho \cdot V \cdot S^{-1}
$$

where $a$ is the rate of increase of the $\mathrm{CO}_{2}\left(\mathrm{ppm} \mathrm{min}{ }^{-1}\right)$, $\rho$ is the $\mathrm{CO}_{2}$ density $\left(\mathrm{mg} \mathrm{m}^{-3}\right), V$ is the collar volume $\left(\mathrm{m}^{3}\right)$, and $S$ is the soil area $\left(\mathrm{m}^{2}\right)$.

In addition, soil temperature, air temperature, and soil moisture (CS615, Campbell Scientific, Logan, UT, USA) were recorded when soil respiration was measured; atmospheric pressure data, from the Korea Meteorological Administration (Seoul, Korea), were also used.

After collecting soil respiration data from the field, all roots were collected from a $30 \times 30 \times 30 \mathrm{~cm}^{3}$ volume at each measurement point and were dried at $80{ }^{\circ} \mathrm{C}$ for $48 \mathrm{~h}$ or more. At the same time, soil was collected from each point at depths of 5 and $30 \mathrm{~cm}$ and organic matter content was analyzed by the ignition loss method.

\section{Results}

Temperature and soil moisture environment

The average monthly ground temperature in the measurement period is shown in Fig. 1. The average ground temperature in summer (August 15) was $24.4^{\circ} \mathrm{C}$; from there, it decreased to $16.3{ }^{\circ} \mathrm{C}$ in autumn (October 15); this is the range of temperature change from summer to
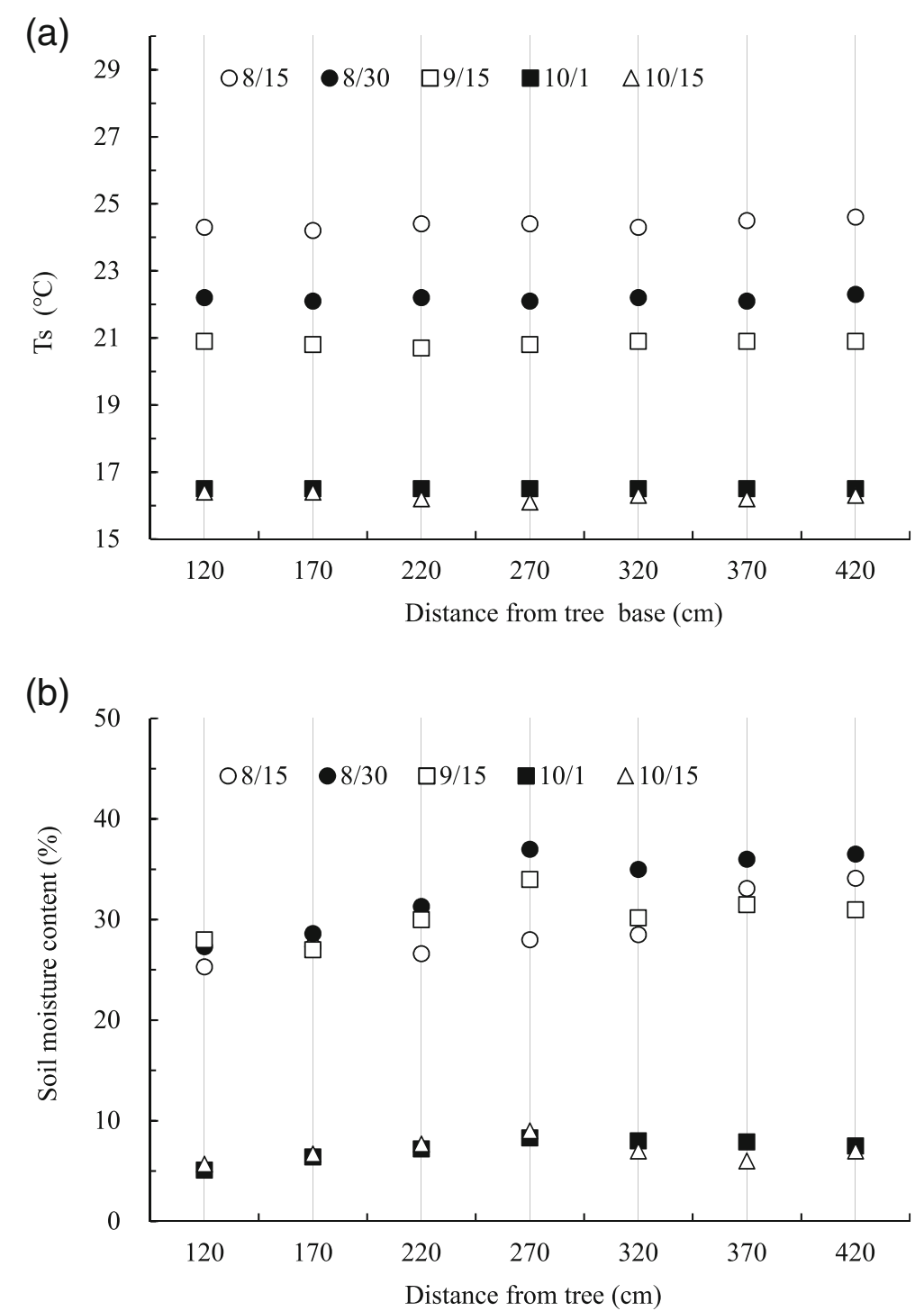

Fig. 1 Soil temperature (a) and soil moisture content (b) of each measurement plot in summer and autumn 
fall (Fig. 1a) and is similar to that in the central part of the Korean Peninsula. In addition, the difference in soil temperature between the measuring points was less than $1{ }^{\circ} \mathrm{C}$, indicating that there is no significant impact of temperature on the size of soil respiration.

On the other hand, soil moisture content showed relatively large differences during the summer season. On August 15, the difference between the measuring points was about $7.8 \%$, ranging from a minimum of $25.3 \%$ to maximally 33.1\%; between August 15 and 30, the moisture content ranged from 27.3 to $37.0 \%$, i.e., a difference of about $10 \%$. This period falls in the summer raining season during which rainfall is concentrated in the monsoon region. However, these differences were significantly reduced to $3.3 \%$ on October 15 , in autumn's dry season (Fig. 1b).

Overall, soil temperature showed a distinct pattern of seasonal variation, and soil moisture content was high in summer when rainfall is high and vice versa in the winter season, demonstrating the general changes in temperature and soil moisture content of monsoon regions.

\section{Soil respiration}

\section{Seasonal aspect of soil respiration}

Soil respiration, measured from the high-temperature season of summer to the low-temperature season of autumn, showed typical seasonal changes during the measurement period, being high in summer and low in the fall. Soil respiration peaked from the beginning of August to September and then began to decrease until the end of October. During the measurement period, soil respiration generally showed a change from high to low values with varying soil temperatures (Fig. 2a).

The seasonal change of soil respiration was highly related to changes in soil temperature in all measurement
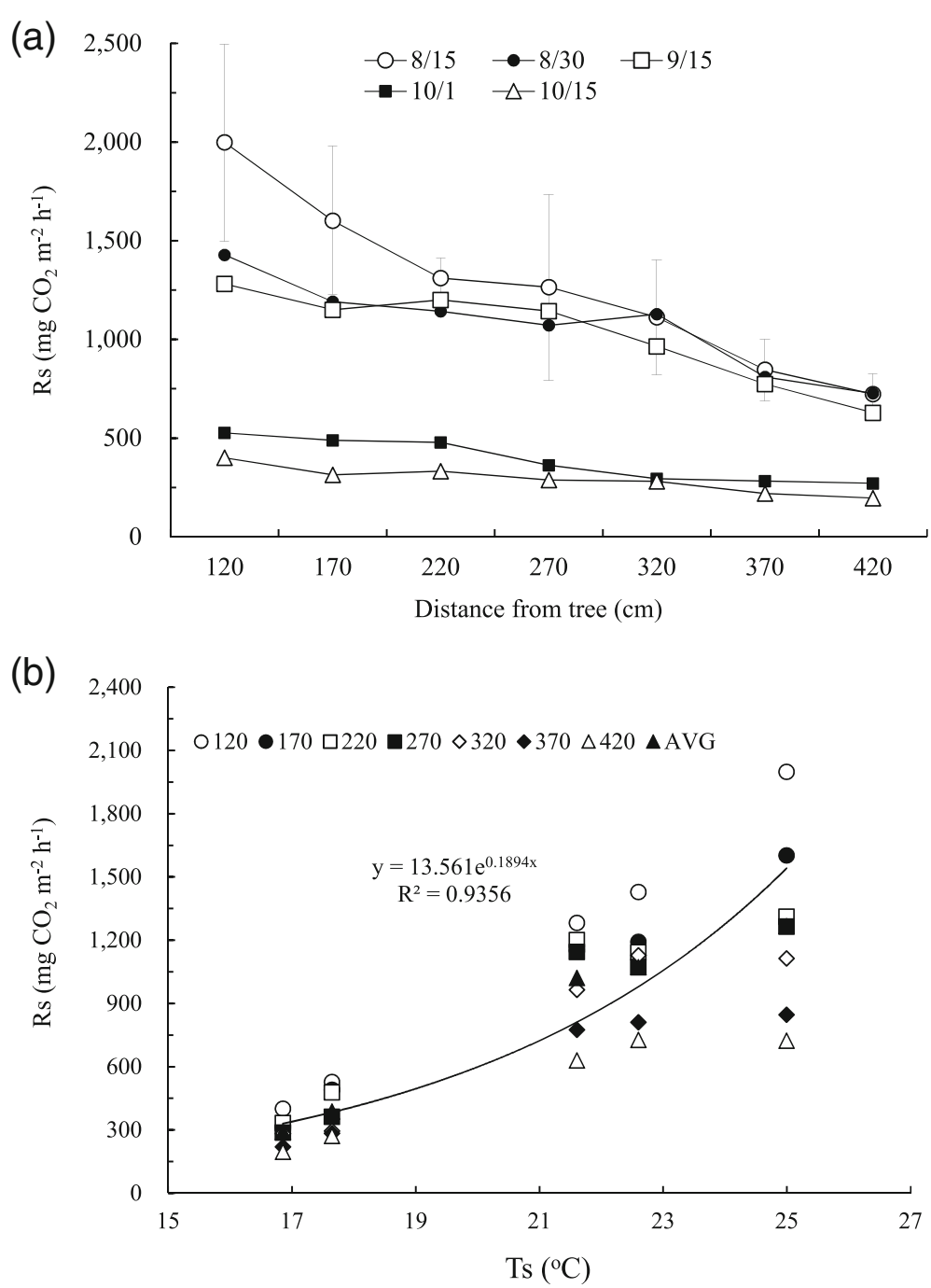

Fig. 2 Changes in the relationship between soil respiration $\left(R_{s^{\prime}} \mathbf{a}\right)$ and soil temperature $\left(T_{s^{\prime}} \mathbf{b}\right)$ in each measurement plot 
plots. The $R^{2}$ value for the regression between soil temperature and respiration was very high for each measuring point, from 0.90 to 0.98 . Averaging over all season and all points, the $R^{2}$ value was 0.94 , which is a very high value (Fig. 2b). This is a general tendency for temperate zones during the monsoon season, indicating that the study site shows soil respiration characteristics that are typical for the ecosystem and that the measurement point is a very suitable place to collect data for the purposes of this study.

\section{Tree position and soil respiration}

In general, as the distance from the base of the tree increases, soil respiration (Fig. 2a) tends to decrease. Over the entire measurement period, the level of soil respiration was highest on August 15, with high values of 1998.3, 1601.9, and $1310.3 \mathrm{mg} \mathrm{CO} \mathrm{m}^{-2} \mathrm{~h}^{-1}$ at 120,170 , and $220 \mathrm{~cm}$, respectively. The soil respiration gradually decreased from 270 to $420 \mathrm{~cm}$ distance from the tree base and was $722.9 \mathrm{mg} \mathrm{CO} \mathrm{m}^{-2} \mathrm{~h}^{-1}$ at $420 \mathrm{~cm}$. When soil respiration was at its highest level, the value at $120 \mathrm{~cm}$ was approximately 2.8 times higher than the lowest value, at $420 \mathrm{~cm}$.

However, on October 15, it was $400.3 \mathrm{mg} \mathrm{CO}_{2} \mathrm{~m}^{-2} \mathrm{~h}^{-1}$ at $120 \mathrm{~cm}$ and decreased as the distance from the tree increased. At $420 \mathrm{~cm}$, the farthest point measured, it was $196.1 \mathrm{mg} \mathrm{CO} \mathrm{m}^{-2} \mathrm{~h}^{-1}$, i.e., $49.0 \%$ of the value at $120 \mathrm{~cm}$. Also, on September 15, when the overall value was moderate, soil respiration at 120,170 , and $220 \mathrm{~cm}$, where the values are relatively high compared to those at the other measurement points, was $1381.3,1150.3$, and $1200.4 \mathrm{mg}$ $\mathrm{CO}_{2} \mathrm{~m}^{-2} \mathrm{~h}^{-1}$, respectively. At $270,320,370$, and $420 \mathrm{~cm}$, the values were gradually decreased, being 1143.3, 964.2,
773.6, and $628.5 \mathrm{mg} \mathrm{CO} \mathrm{m}^{-2} \mathrm{~h}^{-1}$, respectively: results at other measurement times were similar (Fig. 2a). In general, the difference between soil respiration was shown to be high in periods of high temperature and small at low temperatures.

As a result, although there were slight variations due to soil temperature decreases, the tendency of the soil respiration value to decrease from high to low as distance increases from the base of the tree was very clear.

\section{Root biomass distribution}

The distribution of root biomass with increasing distance from the tree is shown in Fig. 3. As shown, as the distance from the tree increases, the root biomass tends to decrease exponentially. At $120 \mathrm{~cm}$ from the tree, it was $1712 \mathrm{~g}$ per $0.027 \mathrm{~m}^{3}$, but at $170 \mathrm{~cm}$, it dropped to $1120 \mathrm{~g}$, which was $65.4 \%$ of the value at $120 \mathrm{~cm}$. At 220, 270, 320, 370, and $420 \mathrm{~cm}$, it was $780(45.6 \%), 460$ (26.9\%), $102(5.9 \%)$, and $11 \mathrm{~g}(0.6 \%)$, respectively. The root biomass $(y)$ tends to decrease exponentially with increasing distance from the tree $(x)$, according to the function $(y)=-1437 \ln (x)+8530.3\left(R^{2}=0.98\right)$. No roots were collected at $470 \mathrm{~cm}$, the measuring point farthest from the tree, and soil respiration originated solely due to microbial respiration at this point.

\section{Relationship between root biomass and soil respiration}

The relationship between the root biomass of the tree and soil respiration is shown in Fig. 4. As shown, there is a very high correlation between root biomass and soil respiration. This relationship showed that soil respiration $(y)$ is very highly exponentially correlated $\left(R^{2}=\right.$ 0.80 ) with root biomass $(x): y=101.36 \ln (x)+419.1$. Soil

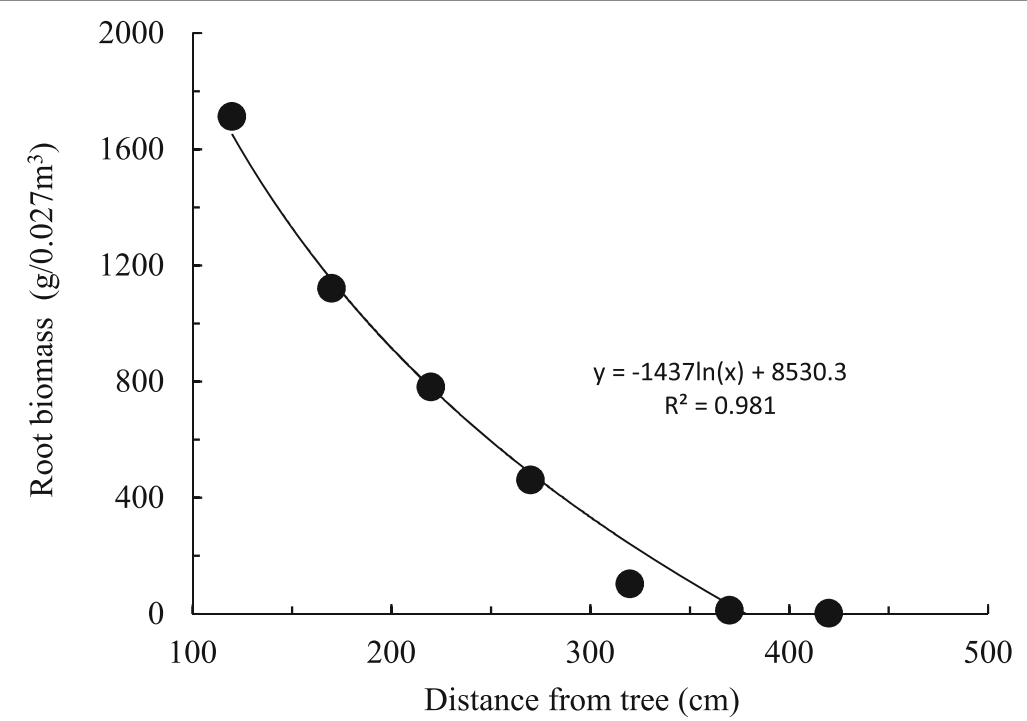

Fig. 3 Distribution of root biomass $\left(R_{\mathrm{m}}\right)$ according to distance from tree base. Root was collected from each measurement point $\left(0.3 \times 0.3 \times 0.3 \mathrm{~m}^{3}\right)$ 


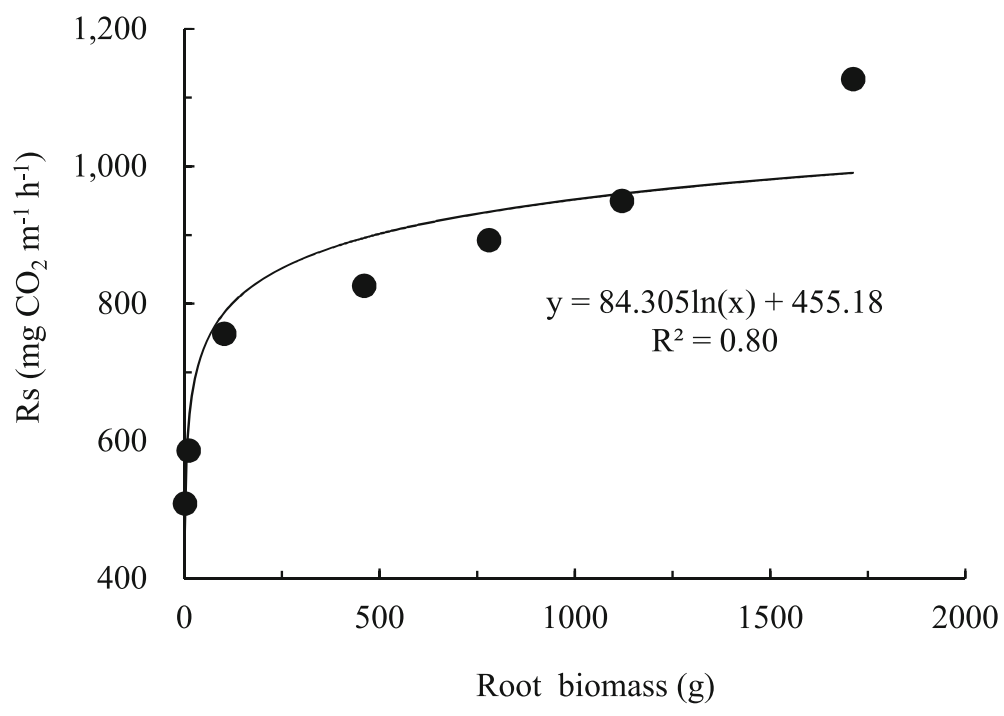

Fig. 4 Relationship between root biomass $\left(R_{\mathrm{m}}\right)$ and soil respiration $\left(R_{\mathrm{s}}\right)$

respiration showed a tendency to increase rapidly with root biomass starting at the point where the roots began to appear.

On the other hand, the soil respiration at $420 \mathrm{~cm}$, where no roots were collected at our site, was regarded as pure microbial respiration. Using this assumption, we calculated how much of the value remained after subtracting the soil respiration at $420 \mathrm{~cm}$ from the soil respiration value recorded at each measurement point (Fig. 5). These results indicate the proportion of root respiration in the total soil respiration at each measurement point. The highest value was found at $120 \mathrm{~cm}$ at $43.1 \%$ and decreased to $32.9 \%, 28.9 \%, 40.5 \%$, and $26.6 \%$ at $170,220,270$, and $320 \mathrm{~cm}$, respectively. Overall, the average value was $31.1 \%$, excluding the value at $370 \mathrm{~cm}$, where few roots were observed.

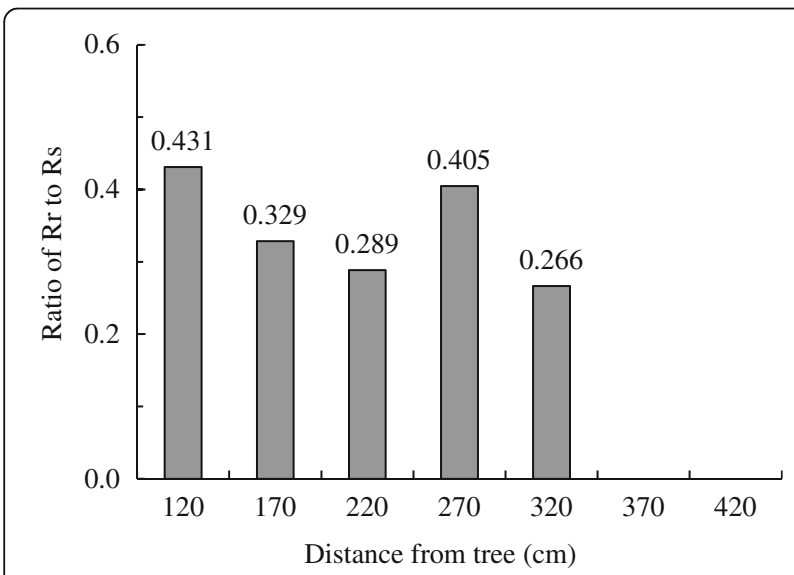

Fig. 5 Ratio of root respiration $\left(R_{\mathrm{r}}\right)$ to soil respiration $\left(R_{\mathrm{s}}\right)$ in each measurement plot
The relationship between root respiration and root biomass as shown in Fig. 6, as well as the change in root respiration for soil respiration, showed that the root biomass per unit weight tended to decrease highly toward the base part. In the point of $370 \mathrm{~cm}$ from the base, the ratio of root respiration per unit root weight was 7.03, but it was 2.42 at $320 \mathrm{~cm}$ and 0.69 at $270 \mathrm{~cm}$ (Fig. 6). Also, it was shown relatively low and similar values ranged from 0.49 to 0.36 in $220 \mathrm{~cm}$ to $120 \mathrm{~cm}$.

\section{Discussion}

The seasonal variation of the soil temperature was significantly higher during the summer season than during autumn; the average was $24.4{ }^{\circ} \mathrm{C}$ in summer and $16.3{ }^{\circ} \mathrm{C}$ in autumn (Fig. 1a). The difference between measurement plots was very small. Therefore, the difference in

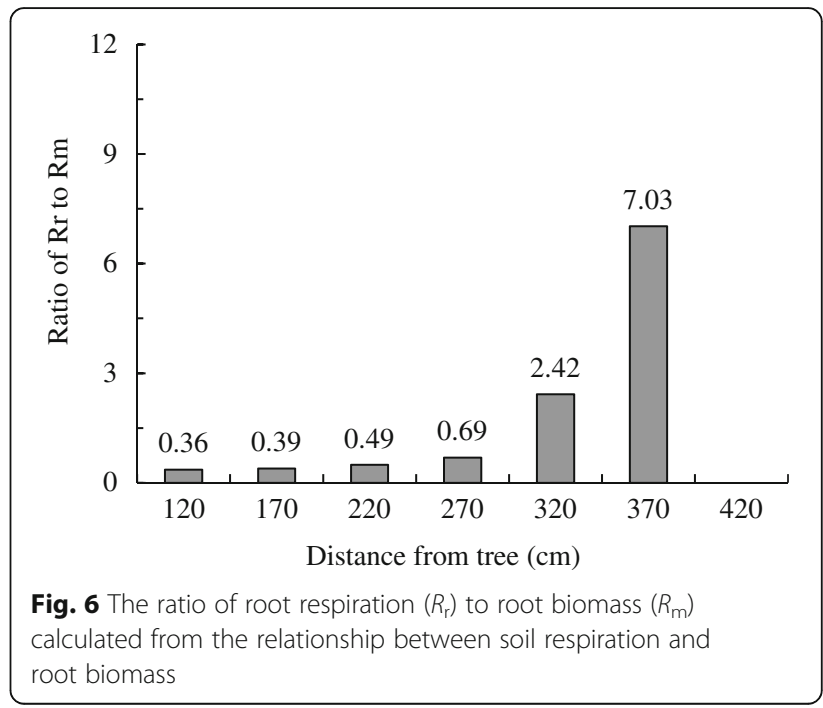


temperature between measurement points was not considered to be a factor affecting soil respiration. In general, in spatially small-range studies, the difference in soil temperature is not significant and does not significantly affect the difference in soil respiration between measurement points. However, seasonal changes in the soil temperature are significant and affect soil respiration (Meentemeyer 1984; Eom et al. 2018; Jeong et al. 2017). However, possibly, soil moisture was slightly influenced by the measurement time, ranging from a low of about $25.3 \%$ to a high of $34.1 \%$, i.e., a difference of $8.8 \%$, which affected soil respiration (Klimek et al. 2009; Xu and Qi 2001; Suh et al. 2009).

As shown in Fig. 1b, soil moisture tends to increase with distance from the trees, probably due to drying as a result of soil moisture absorption by roots. This tendency showed a sharp increase between 220 and $270 \mathrm{~cm}$, which is where the thick roots near the tree base are replaced by relatively thin roots. However, whether the difference in soil moisture is caused by the amount of root distributed at the measurement point or by a difference in the proportion of coarse and fine root was determined to be by the latter (Boone et al. 1998).

As a result, the soil temperature and soil respiration showed a clear seasonal change from a high value in summer to a low value in autumn (Fig. 2a). In addition, soil respiration differences between measurement points showed a tendency to be relatively larger at high than at low temperatures. The range of seasonal variation of the soil respiration increased when coming closer to the tree, and the range decreased with distance from the tree. This means that the closer to the base, the more sensitive soil respiration is to temperature changes, while it becomes less sensitive to temperature changes with increasing distance from the base (Fig. 2a; Bond-Lamberty et al., 2004a, b).

On the other hand, the distribution of root biomass with distance from the tree was highest near the tree's base and decreased exponentially with increasing distance from the tree (Fig. 3, Pregitzer et al. 1998; Dannoura et al. 2008; Cairns et al. 1997).

These results indicate that the root biomass at the tree base decreases very steeply with increasing distance from the base. This exponential distribution of roots induces a difference in the distribution of resources such as water and minerals in the soil used by the tree and is considered to affect the distribution and activity of symbiotic and non-symbiotic organisms living in the soil. The distribution characteristics of these roots, shown in Fig. 4, display a very high correlation with soil respiration.

In this study, the soil respiration value $(y)$ was analyzed to increase with the amount of root $(x)$ as $y=$ $101.36 \ln (x)+419.1\left(R^{2}=0.93\right)$. This high correlation can be interpreted as a sign that plant roots have a clear influence factor on the value of the soil respiration.

The relationships between soil respiration and root biomass and root respiration, respectively, adjusted for microbial respiration at the points not containing roots, are shown in Figs. 4 and 5. The ratios are $26.6 \%$ and $43.1 \%$, respectively. The mean value is $34.4 \%$, which is within the range suggested in previous studies, and the method proposed in this study is suitable for estimating root volume by soil respiration (Kucera and Kirkham 1971; Chapman 1979; Coleman 1973; Son and Kim 1996; Lee et al. 2012). However, since the tree size in this study is very limited, more research will be necessary, including the collection and analysis of additional data on different tree species, tree sizes, and cluster densities.

Most especially, there have been many papers that show fine roots are very dynamically affected in the carbon cycle of soils (Lee and Jose 2003; Tufekcioglu et al. 1998; Fisk et al. 2004). In fact, in this study, the root respiration according to the increase of the distance from the tree base was higher at the far position than near the base (Fig. 6). This may be due to the fact that the respiratory activity of fine root is relatively very higher than that of thick root. Therefore, it is very important to understand the composition characteristics of root sizes in addition to the distribution of root biomass according to the size of trees (Paterson et al. 2008).

\section{Conclusion}

It is very difficult to distinguish among soil respiration, root respiration, and microbial respiration in the forest ecosystem's carbon cycle. Various classification methods have been attempted to distinguish them, but a clear and easily applicable method has not been established yet. In this study, we attempted to determine the root volume by analyzing the distribution of root biomass and the change in soil respiration according to the distance from the base of the tree. The results showed that the underground distribution of the roots of trees showed a tendency to decrease exponentially with increasing distance from the base of the trees and to decrease with increasing distance.

Also, soil respiration and root volume were logarithmically related, and the proportion of root respiration rate in soil respiration was calculated to be about $34.4 \%$. This proportion was obtained from a limited number of samples, and it is necessary to verify its accuracy. However, considering that the purpose of this study was to examine whether the new classification method is applicable, if additional research confirms the results, it may be considered to be highly so. 


\section{Abbreviations}

a: Rate of increase of $\mathrm{CO}_{2} ; R_{\mathrm{h}}$ : Heterotrophic respiration; $R_{\mathrm{m}}$ : Root biomass; $R_{\mathrm{r}}$ : Root respiration; $R_{\mathrm{s}}$ : Soil respiration; $S$ : Soil area; $T_{\mathrm{s}}$ : Soil temperature; $V$ : Collar volume; $\rho$ : $\mathrm{CO}_{2}$ density

\section{Acknowledgements}

Not applicable

\section{Funding}

This research was supported by the National Research Foundation of Korea (NRF) funded by the Ministry of Science, ICT and Future Planning (NRF2016M3C1B6928005).

\section{Availability of data and materials}

Not applicable

\section{Author's contributions}

The author conceived the study, collected the data, interpreted the results, and wrote the manuscript. The author read and approved the final manuscript.

\section{Ethics approval and consent to participate}

Not applicable.

\section{Consent for publication}

Not applicable.

\section{Competing interests}

The author declares that he has no competing interests.

\section{Publisher's Note}

Springer Nature remains neutral with regard to jurisdictional claims in published maps and institutional affiliations.

Received: 5 September 2018 Accepted: 7 October 2018

Published online: 22 October 2018

\section{References}

Bond-Lamberty B, Wang C, Gower ST. A global relationship between the heterotrophic and autotrophic components of soil respiration? Glob Chang Biol. 2004a; 10:10

Bond-Lamberty B, Wang C, Gower ST. Contribution of root respiration to soil surface $\mathrm{CO}_{2}$ flux in a boreal black spruce chronosequence. Tree Physiol. 2004b;24:1387-95.

Boone RD, Nadelhoffer KJ, Canary JD, Kaye JP. Roots exert a strong influence on the temperature sensitivity of soil respiration. Nature. 1998;396:570-2

Cairns MA, Brown S, Helmer EH, Baumgardner GA. Root biomass allocation in the world's upland forests. Oecologia. 1997:111:1-11.

Chapman SB. Some interrelationship between soil and root respiration in lowland calluna heathland in southern England. Ecology. 1979;67:1-20

Coleman D. Compartmental analysis of total soil respiration: an exploratory study. Oikos. 1973;24:465-8.

Dannoura M, Kominami Y, Oguma H, Kanazawa Y. The development of an optical scanner method for observation of plant root dynamics. Plantroot. 2008;: : :14-8.

Eom JY, Jeong SH, Chun JH, Lee JH, Lee JS. Long-term characteristics of soil respiration in a Korean cool-temperate deciduous forest in a monsoon climate. Anim Cells Syst. 2018;22(2). https://doi.org/10.1080/19768354.2018.1433234.

Fisk MC, Fahey TJ, Groffman PM, Bohlen PJ. Earthworm invasion, fine-root distributions, and soil respiration in north temperate forests. Ecosystems. 2004; 7:55-62.

Hanson PJ, Edwards NT, Garten CT, Andrews JA. Separating root and soil microbial contributions to soil respiration: a review of methods. Biogeochemistry. 2000;48:115-46.

IPCC. Summary for Policymakers. In: Parry ML, Palutiof OF, van der Linden PJ, Hanson CE, editors. Climate Change 2007: Impacts, Adaptation and Vulnerability. Contribution of Working Group II to the Fourth Assessment Report of Report of the Intergovernmental Panal on Climate Change. Cambridge: Cambridge University Press; 2007. p. 7-22.

Jeong SH, Eom JY, Lee JH, Lee JS. Effect of rainfall events on soil carbon flux in mountain pastures. J Ecol Environ. 2017;41:37.
Klimek B, Choczyn' ski M, Juszkiewicz A. Scots pine (Pinus sylvestris L) roots and soil moisture did not affect soil thermal sensitivity. Eur J Soil Biol. 2009:45:442-7.

Kucera CL, Kirkham DR. Soil respiration studies in tallgrass prairie in Missouri. Ecology. 1971;52:912-5.

Kuzyakov Y, Larionova A. Root and rhizomicrobial respiration: a review of approaches to estimate respiration by autotrophic and heterotrophic organism in soil. J Plant Nutr Soil Sci. 2005;168:1-18.

Lamberty BB, Wang C, Gower ST. Contribution of root respiration to soil surface $\mathrm{CO}_{2}$ flux in a boreal black spruce chronosequence. Tree Physiol. 2004;24: 1387-95.

Lee JH, Eom JY, Jeong SH, Hong SB, Park JY, Lee JS. Influence of carbonized crop residue on soil carbon storage in red pepper field. J Ecol Environ Sci. 2017;41:40.

Lee $\mathrm{KH}$, Jose $\mathrm{S}$. Soil respiration, fine root production, and microbial biomass in cottonwood and loblolly pine plantations along a nitrogen fertilization gradient. For Ecol Manag. 2003;185:263-73.

Lee KJ, Won HY, Mun HT. Contribution of root respiration to soil respiration for Quercus acutissima forest. Korean J Environ Ecol. 2012;26:780-6.

Meentemeyer $\mathrm{V}$. The geography of organic decomposition rates. Ann Assoc Am Geogr. 1984;74:551-60.

Millard P, Midwood AJ, Hunt JE, Whitehead D, Boutton TW. Partitioning soil surface $\mathrm{CO} 2$ efflux into autotrophic and heterotrophic components, using natural gradients in soil d13C in an undisturbed savannah soil. Soil Bio. \& Biochem. 2008;40:1575-82.

Paterson E, Thornton B, Midwood AJ, Osborne SM, Sim A, Millard P. Atmospheric $\mathrm{CO}_{2}$ enrichment and nutrient additions to planted soil increase mineralization of soil organic matter, but do not alter microbial utilisation of plant- and soil C-sources. Soil Biol Biochem. 2008;40:2434-40.

Pregitzer KS, Laskowski MJ, Burton AJ, Lessard VC, Zak DR. Variation in sugar maple root respiration with root diameter and soil depth. The Physiology. 1998;18:665-70.

Ryan MG, Law BE. Interpreting, measuring, and modeling soil respiration. Biogeochemistry. 2005;73:3-27.

Son YH, Kim HW. Soil respiration in Pinus rigida and Larnix leptolepis plantation. Jaunal of Korean Forest Societ. 1996;85:496-505.

Suh SU, Chun YM, Chae NY, Kim J, Lim JH, Yokozawa M, Lee MS, Lee JS. A chamber system with automatic opening and closing for continuously measuring soil respiration based on an open-flow dynamic method. Ecol Res. 2006;21:405-14.

Suh SU, Lee EH, Lee JS. Temperature and moisture sensitivities of $\mathrm{CO}_{2}$ efflux from lowland and alpine meadow soils. J Plant Ecol. 2009;2(4):225-31.

Tufekcioglu A, Raich JW, Isenhart TM, Schultz RC. Fine root dynamics, coarse root biomass, root distribution, and soil respiration in a multispecies riparian buffer in Central lowa, USA. Agrofor Syst. 1998:44:163-74.

Vose JM, Ryan MG. Seasonal respiration of foliage, fine roots, and woody tissues in relation to growth, tissue N, and photosynthesis. Glob Chang Biol. 2002;8:182-93.

Wang W, Feng J, Oikawa T. Contribution of root and microbial respiration to soil $\mathrm{CO}_{2}$ efflux and their environmental controls in a humid temperate grassland of Japan. Pedosphere. 2009;19(1):31-9.

Xu M, Qi Y. Soil-surface $\mathrm{CO}_{2}$ efflux and its spatial and temporal variations in a young ponderosa pine plantation in northern California. Glob Chang Biol. $2001 ; 7: 667-77$.

Ready to submit your research? Choose BMC and benefit from:

- fast, convenient online submission

- thorough peer review by experienced researchers in your field

- rapid publication on acceptance

- support for research data, including large and complex data types

- gold Open Access which fosters wider collaboration and increased citations

- maximum visibility for your research: over $100 \mathrm{M}$ website views per year

At $\mathrm{BMC}$, research is always in progress.

Learn more biomedcentral.com/submission 